\title{
Closing the age gap? Age, skills and the experience of work in Great Britain
}

\author{
ALAN FELSTEAD*
}

\begin{abstract}
Populations across Europe are ageing as death rates among the old and fertility rates among the young fall. This produces a number of long-term challenges for national governments - most notably, coping with the increased demand for social services, pensions and benefits that must be funded by a declining proportion of working adults. One policy response has been to extend people's working lives, but we know relatively little about the skills and employment experiences of older workers and how these compare with younger workers. This paper sheds new light on this issue by examining whether older workers do less well than their younger counterparts in terms of the skills of the jobs they hold, the quality of their working lives, their commitment to their current employer and to employment in general, and their attitudes towards and experiences of training. The paper also assesses whether these age gaps have closed over time. The empirical evidence for the paper is from five separate but comparable surveys carried out in I986, I992, I997, 200 I and 2006. Taken together, the five surveys provide information on the employment experiences of over 22,000 workers in Great Britain. This allows us to chart whether we are witnessing the disappearance of at least some of the age divisions in the labour market.
\end{abstract}

$\boldsymbol{K E Y} \boldsymbol{W} \boldsymbol{O R} \boldsymbol{D} \boldsymbol{S}$ - ageing, employment, quality of work, skills, training.

\section{Introduction}

Populations across the developed world are ageing and the pace of change is accelerating. For example, in 2007, less than one-fifth of the European population was aged 65 or more years, but by 2032 the share is predicted to rise to around one-quarter (Dunnell 2008; Lutz 2008). The reason is that across the developed world, the end of the Second World War was followed by a rise in the number of births - the so-called 'baby boom'. This means that large numbers of workers will leave the labour market during the next decade and start to claim pensions and other social-security benefits. This has led to several Europe-wide policy

* Cardiff School of Social Sciences, Cardiff University, Cardiff, UK. 
responses, most notably measures to raise the retirement age and to increase the employment rate of those aged 55-64 years (European Commission 2003: 28-29). Individual governments, too, have responded to the demographic challenge by launching initiatives to extend working life. In the United Kingdom (UK), for example, these include: the introduction of legislation making it unlawful to discriminate in employment and training matters on the grounds of age (Minister of State for Employment 2006); a commitment to raising women's State Pension Age (SPA) from 60 to 65 years by 2020, and a suggestion that once aligned for men and women, the pension age will be raised to 68 years by the middle of the century (Department for Work and Pensions (DWP) 2005; Turner 2006); the introduction of a scheme which allows people to defer the date at which they receive the state pension in return for a higher amount or a lump sum when they decide to do so (Whiting 2005); and the establishment of a separate Extending Working Life unit in the DWP.

The research community has responded accordingly with the result that we now know much more about how and in what ways older workers differ from their younger colleagues, what discourages people from staying in work longer and what might encourage them to stay longer or delay their retirement, and what aspects of work older workers value most (Hirsh 2003; Walker 2004). As the following section will show, however, little is known about the skills content of older workers' jobs, how their experiences and commitment to work differs from younger workers, and how if at all - these generational differences have changed over time. The aim of this paper is to address these research questions with empirical evidence taken from five separate but comparable surveys carried out in Ig86, I992, I997, 200I and 2006. Taken together, the five surveys contain information - not regularly collected by other sources - on the jobs held by over 22,000 workers in Great Britain. The paper outlines how these surveys were carried out and the measures that have been taken for this paper to ensure that representative data are reported. In this way, the substantive empirical section of the paper provides new and original comparative data on the skills content of the jobs done by 'old', 'middle aged' and 'young' workers, the quality of their working lives, their commitment to their current employers and to employment in general, and their attitudes towards and experiences of training. Where the data allow, the paper also discusses how these patterns have changed over the last two decades, offers some explanations, and ends by summarising the main identified trends which suggest that in some respects age divides in the labour market have weakened. A remaining task for future gerontology research is to assess the extent to which this process continues. 


\section{The state of the debate on older workers}

Given the increased policy emphasis in the UK on lengthening working lives, it is not surprising that there have been many studies of the employment, activity and inactivity rates of older people (e.g. Disney and Hawkes 2003; Faggio and Nickell 2003; Hotopp 2005; Laczko and Phillipson 199i). These have been based on general purpose surveys such as the Labour Force Survey, the General Household Survey and the population census. More specific surveys, reviews and qualitative studies on older people have also been carried out. For example, in 2002 the DWP commissioned the Older Workers' Survey which gathered data from 2,808 people aged 50-69 years. Its primary aim was to identify what factors encourage labour-market participation and influence labour-market withdrawal among those close to retirement (Humphrey et al. 2004). A survey of similar size was carried out a few years later in the run-up to the introduction of the anti-age discrimination legislation, but this time directed to employers. That study was designed to establish how much employers' employment policies and practices - on recruitment, promotion, pay, training and redundancy-needed to change in order to meet legislative standards (Metcalf and Meadows 2006). In early 2009, the Equality and Human Rights Commission sponsored another survey of I,494 people aged 50-75 years as part of its 'Working Better' programme. That study elicited views on the benefits, barriers and their motivations towards work (Smeaton, Vegeris and SahinDikmen 2009).

The retirement decision-making process has also been examined in a number of workplace contexts, including the information technology industry, the civil service, the higher-education sector and television broadcasting (Brooke 2009; Higgs et al. 2003; Platman and Tinker 1998; Stein, Rocco and Goldenetz 2000). The role of employers in this process has been of particular interest in the light of suggestions that older workers experience discrimination when employers decide to trim (or expand) their workforces (McNair and Flynn 2005; Vickerstaff 2006). In addition, there have been a number of comprehensive and thorough literature reviews on older workers (e.g. Meadows 2003; Phillipson and Smith 2005; Urwin 2004).

Research that focuses on the employment experience of older workers is, however, relatively rare. What we do know relates, in the main, to the characteristics of their employment, such as the contractual nature of the jobs they hold, what occupations they occupy and whether they receive job-related training (Barnes, Smeaton and Taylor 2009; Khan 2009; Lissenburgh and Smeaton 2003; Platman 2004; Urwin 2004). Yet while 
we know that older workers are less likely to receive training than younger workers, it is unclear 'how far this is a matter of employer resistance, or individual unwillingness to train' (McNair 2006: 493). Even research which seeks to offer such a perspective is limited. For example, in 2003 five questions were added to the Office for National Statistics Omnibus Survey on the frequency, causes and outcomes of job change. In 2004, a follow-up sample was asked a further 44 questions that covered what was liked and disliked about work, how long the respondents expected to work, what they aspired to achieve in their career, and what attitudes they had about retirement. Unfortunately, however, only those aged 50 or more years in the original national sample were asked these questions, limiting our ability to compare attitudes by age (McNair 2006).

To examine the skills, experiences and attitudes of older workers in comparison with younger age groups, data have to be collected from all age groups. While general multi-purpose surveys have provided valuable insights, these are broad survey instruments and hence the time devoted to collecting focused experiential and attitudinal data is limited. Specialist surveys of employment and working conditions are much better placed to offer such insights, but few have been analysed from an age perspective. Moreover, in some analyses of the changing labour market, age is barely mentioned and some books on the subject do not even index the topic (mea culpa, see Felstead et al. 2007b).

There are notable exceptions. The European Working Conditions Survey (EWCS) carried out in 2005, for example, has been analysed from an age perspective (Villosio 2008), but the results were presented at a European not the country level, for which the sample sizes are relatively small, e.g. $\mathrm{I}, 058$ for the UK. Furthermore, although the fourth EWCS was carried out in 2005, its content has been expanded considerably since the initial survey in I990, so its ability to track change over time is confined to the questions which appeared in identical form at each data collection point. Nevertheless, the EWCS shows that older workers (here defined as aged 55 or more years) had higher levels of autonomy and worked in less intensive jobs than younger workers (Villosio 2008: 42). Another exception has been an analysis of changes in the strength of attachment that workers have to the organisations for which they work (White 2009). This was based on two surveys carried out in Great Britain in 1992 and 2000. The data show that while older workers (here defined as those aged 45 or more years) were more loyal to the organisation they worked for than their younger counterparts in 1992, this was no longer the case in 2000.

The aim of this paper is to add to the evidence base in two ways. First, by analysing the comparative fortunes of 'old', 'middle aged' and 
'young' workers in terms of the skill content of the jobs they hold, the intensity of work, their organisational and employment commitments, and experiences of training. Secondly, by tracking how these patterns have changed over the last two decades, the paper provides a more comprehensive assessment of the changing quality of jobs by age than has hitherto been accomplished.

\section{Data sources}

The data used for this paper are drawn from five nationally-representative sample surveys carried out in Great Britain in 1986, I992, I997, 200 and 2006 (the 2006 survey also included Northern Ireland, so when evidence is presented from this source alone nationally-representative refers to the UK). The surveys used are: the Social Change and Economic Life Initiative survey carried out in I986 (Penn, Rose and Ribery 1994); the Employment in Britain survey carried out in 1992 (Gallie et al. 1998); and the three Skills Surveys carried out in 1997, 200 I and 2006 (Ashton et al. 1999; Felstead, Gallie and Green 2002; Felstead et al. 2007b). These five crosssectional surveys allow us to chart whether we are witnessing the disappearance of some age divisions in the labour market. For the most part, we focus on identical questions that were asked of respondents in at least three of these five surveys. On this basis, we are able to comment on how the experience of work varied by age in Great Britain in recent times and how, if it all, it has changed over time. All five surveys were nationallyrepresentative sample surveys of individuals in employment aged 20-60 years old (although the 2006 survey did additionally sample those aged 6I-65 years). Each had a large sample size: the ig86 survey had 4,047 respondents; the 1992 survey had 3,855 ; the 1997 had 2,467; the $200 \mathrm{I}$ survey had 4,470; and the 2006 survey had 7,787 (see Felstead et al. 2007 b). For each survey, sample weights were computed to take into account the differential probabilities of sample selection according to the number of dwelling units at each issued address, the number of eligible interview respondents, the over-sampling of the boost areas and the slight underrepresentation of certain groups. All the presented analyses use these weights. In line with both academic and policy convention, the paper defines 'older' workers as those aged between 50 years and the SPA (Khan 2009). In operational terms, this equates to 50-60-year-olds, given that those aged $6 \mathrm{I}-65$ years were not canvassed in four of the five surveys drawn upon here. In order to compare their experiences with younger employees, we define the 'young' as those aged 20-34 years and the 'middle aged' as those aged 35-49 years. 


\section{The older workers' experience}

Despite the keen interest in how skills have changed over time, how they are distributed, and how the trends and patterns compare with competing nations, there is surprisingly little agreement about what 'skills' actually refer to. Despite different emphases and nuances, however, many studies have focused on the nature of the job, including the abilities and techniques required, the intricacies of its tasks, and the knowledge of equipment, products and processes needed for competent performance. In this paper, the complexity of jobs is measured in two ways. First, the abilities and capacities of those in employment are inferred from information about the attributes required for the job. These broad skill measures include: the required qualifications; the length of training required; and the time taken to learn to do the job well. Secondly, the generic skills demanded of those in work are also examined. These were measured by asking job-holders to rate the importance of particular activities to their work.

Tables I and 2 show how the skills content of the jobs of young, middleaged and older workers have changed over the last two decades. Each respondent was asked to judge what qualifications would now be required to get his or her current job. They were asked: 'If they were applying today, what qualifications, if any, would someone need to get the type of job you have now?' Respondents were placed into one of five categories according to the highest qualification they mentioned (coded 'o' to ' 4 '). A 'Required Qualifications Index' was derived as a summary measure. On average, one-in-five jobs required Level 4 or higher qualifications for entry in I986, but by 2006 this had risen to three-in-ten. The same pattern was repeated at the other end of the scale, where over the same period there was an II percentage point drop in the proportion of jobs requiring no qualifications for entry (average figures for all workers regardless of age or sex). Analysis by age shows that older workers fared better than their younger counterparts. The 'Required Qualification Index' rose more rapidly among older workers than among the young - from I.7I for older men and I.04 for older women in I986 to I.95 and 2.01, respectively. This compares to slower rises for the jobs held by young men (I.88 to I.97) and young women (I.55 to 2.07). Moreover, the age gap between the young and old became statistically insignificant for both sexes in 2006; in I986, older workers of either sex were in jobs that required statistically lower qualifications for entry ( $p<$ o. I for men, $p<$ o.or for women).

The second broad skill measure is based on responses to a series of questions on the duration of training required for the particular type of work carried out by the respondent. It is based on the premise that the required duration for different jobs reflected the ability level and 
T A в L E I. Broad skills by age, men, Great Britain, 1986-20o6

\begin{tabular}{|c|c|c|c|c|c|}
\hline Broad skills and age groups & I986 & I992 & I997 & $200 I$ & 2006 \\
\hline & \multicolumn{5}{|c|}{ Sample percentages/scores } \\
\hline \multicolumn{6}{|c|}{$\begin{array}{l}\text { Highest qualification required: } \\
\text { Level } 4 \text { or above: }\end{array}$} \\
\hline $20-34$ & 20.4 & 27.7 & $2 \mathrm{I} \cdot 5$ & 28.5 & 26.4 \\
\hline $35^{-49}$ & $27 \cdot 9$ & $29 \cdot 7$ & $3^{\text {I.o }}$ & 33.2 & 33.9 \\
\hline $5^{0-60}$ & 20.8 & 22.3 & 27.0 & $29 \cdot 7$ & $27 \cdot 7$ \\
\hline \multicolumn{6}{|l|}{ No qualifications: } \\
\hline $20^{-}-34$ & $3^{\mathrm{I} \cdot 4}$ & $29 \cdot 9$ & $3^{1} \cdot 7$ & $24 \cdot I$ & 30.2 \\
\hline $35^{-49}$ & 27.8 & 28.6 & $25 \cdot 6$ & 23.0 & $25 \cdot 4$ \\
\hline $5^{0-6 o}$ & $37 \cdot 3$ & $3^{2.8}$ & 30.6 & 26.2 & $3^{\mathrm{I} . \mathrm{O}}$ \\
\hline \multicolumn{6}{|c|}{ Required Qualification Index: } \\
\hline $20-34$ & I.88 & 2.10 & I.89 & 2.18 & I.97 \\
\hline $35^{-49}$ & 2.14 & $2.2 \mathrm{I}$ & 2.15 & 2.27 & $2.2 \mathrm{I}$ \\
\hline $5^{0-60}$ & I.7I & I.95 & I.99 & 2.II & I.95 \\
\hline \multicolumn{6}{|l|}{ Training time: } \\
\hline \multicolumn{6}{|l|}{$>2$ years: } \\
\hline $20-34$ & 32.4 & 26.4 & $3^{\mathrm{I} \cdot 7}$ & $24 \cdot 7$ & 28.5 \\
\hline $35-49$ & $29 \cdot 6$ & 30.7 & 36.9 & 28. I & 33.6 \\
\hline $5^{0-6 o}$ & $25 \cdot 5$ & 20.0 & 30.6 & 24.8 & 28.I \\
\hline \multicolumn{6}{|l|}{$<3$ months: } \\
\hline $20-34$ & $55 \cdot \mathrm{I}$ & $54 \cdot 5$ & $53 \cdot \mathrm{I}$ & $62 . \mathrm{I}$ & $59 \cdot 3$ \\
\hline $35^{-49}$ & 57.6 & $55 \cdot 6$ & $5^{\mathrm{I} . \mathrm{I}}$ & 57.6 & $54 \cdot 5$ \\
\hline $5^{0-6 o}$ & 68.2 & 72.9 & $6 \mathrm{I} .2$ & 63.2 & 62.5 \\
\hline \multicolumn{6}{|l|}{ Training Time Index: } \\
\hline $20-34$ & 2.65 & 2.57 & 2.72 & 2.26 & 2.40 \\
\hline $35-49$ & $2.5^{2}$ & 2.6I & 2.94 & 2.49 & 2.70 \\
\hline $5^{0-6 o}$ & I.94 & I. 76 & 2.35 & 2.14 & $2 \cdot 3^{\mathrm{I}}$ \\
\hline \multicolumn{6}{|l|}{ Learning time (employees only): } \\
\hline \multicolumn{6}{|c|}{$>2$ years: } \\
\hline $20-34$ & 30.1 & $23 \cdot 5$ & 22.8 & 24.2 & I9.3 \\
\hline $35^{-49}$ & $39 \cdot 4$ & 34.0 & $35 \cdot 3$ & $3^{6.6}$ & 35.8 \\
\hline $5^{\mathrm{o}-6 o}$ & $33 \cdot \mathrm{I}$ & 30.3 & 39.8 & 37.2 & $33 \cdot 3$ \\
\hline \multicolumn{6}{|l|}{ < I month: } \\
\hline $20-34$ & I 7.7 & I $5 \cdot 9$ & I6.3 & 20.0 & 20.4 \\
\hline $35^{-49}$ & I5.8 & I3.6 & $\mathrm{I} 4 \cdot 3$ & II. 8 & I 2.5 \\
\hline $5^{0-6 o}$ & $24 \cdot 7$ & 24.0 & I6.4 & I8.2 & I9.0 \\
\hline \multicolumn{6}{|l|}{ Learning Time Index: } \\
\hline $20-34$ & $3 \cdot 72$ & 3.62 & $3 \cdot 57$ & $3 \cdot 5^{\circ}$ & $3 \cdot 3^{8}$ \\
\hline $35^{-49}$ & 4.07 & $4 . \mathrm{OI}$ & 4.03 & 4.18 & $4 \cdot 12$ \\
\hline $5^{0-6 o}$ & $3 \cdot 57$ & 3.64 & 4.07 & 4.04 & 3.86 \\
\hline
\end{tabular}

Note: Respondents in all five surveys were asked: 'If you were applying today, what qualifications, if any, would someone need to get the type of job you have now?' A range of options was given, and the highest qualification identified. In both 2006 and 200I, the categorisation was in broad terms as follows. Level 4: Postgraduate and undergraduate degrees, professional qualifications. Level 3 : Advanced schooling qualifications many gain at $\mathrm{I} 7^{-1} \mathrm{I}$ years, and comparable vocational qualifications. Level 2: Secondary schooling qualifications many gain at ${ }^{1} 5^{-1} 6$ years, and comparable vocational qualifications. Level $\mathrm{s}$ : Lowest attainment school and vocational qualifications. Details of the allocation of all educational and vocational qualifications offered in England and Wales and in Scotland (where they differ) are available from the author. The derivations of the 'Required Qualifications Index', the 'Training Time Index', and the 'Learning Time Index' are described in the text. 
T A в L E 2. Broad skills by age, women, Great Britain, 1986-2006

\begin{tabular}{|c|c|c|c|c|c|}
\hline Broad skills and age groups & I986 & I992 & I997 & 2001 & 2006 \\
\hline & \multicolumn{5}{|c|}{ Sample percentages/scores } \\
\hline \multirow{2}{*}{\multicolumn{6}{|c|}{$\begin{array}{l}\text { Highest qualification required: } \\
\text { Level } 4 \text { or above: }\end{array}$}} \\
\hline & & & & & \\
\hline $20-34$ & I6.7 & $24 \cdot 6$ & 20.4 & 26.3 & 28.0 \\
\hline $35-49$ & I5.9 & 22.8 & 21.9 & 29.8 & 32.8 \\
\hline $5^{0-6 o}$ & I3.0 & I8.0 & $23 \cdot 5$ & 23.8 & $29 \cdot 7$ \\
\hline \multicolumn{6}{|l|}{ No qualifications: } \\
\hline $20-34$ & $4^{\mathrm{I}} \cdot 4$ & $35 \cdot 2$ & 30.7 & $25 \cdot 7$ & 27.1 \\
\hline $35^{-49}$ & $5^{0.4}$ & 40.2 & 36.9 & 29.2 & $25 \cdot 7$ \\
\hline $5^{0-60}$ & 60.9 & $45 \cdot 2$ & $37 \cdot 3$ & $35 \cdot 3$ & $3^{\mathrm{I}} \cdot 3$ \\
\hline \multicolumn{6}{|c|}{ Required Qualification Index: } \\
\hline $20-34$ & I.55 & I. 86 & I. 86 & 2.03 & 2.07 \\
\hline $35-49$ & I. 34 & I. 72 & I. 72 & $2 . \mathrm{OI}$ & 2.17 \\
\hline $5^{0-60}$ & I.04 & I. 49 & І. 68 & I. 76 & 2.OI \\
\hline \multicolumn{6}{|l|}{ Training time: } \\
\hline \multicolumn{6}{|l|}{$>2$ years: } \\
\hline $20-34$ & I3.I & I7.0 & $24 \cdot \mathrm{I}$ & 20.4 & $25 \cdot 4$ \\
\hline $35-49$ & I0.8 & I5.9 & $23 \cdot 9$ & 22.2 & 29.8 \\
\hline $5^{0-6 o}$ & II.7 & II. 6 & I9.8 & I7.I & 30.1 \\
\hline \multicolumn{6}{|l|}{$<3$ months: } \\
\hline $20-34$ & $73 \cdot 3$ & $65 \cdot 5$ & $5^{8.3}$ & $6 \mathrm{I} \cdot 3$ & $57 \cdot 6$ \\
\hline $35^{-49}$ & 77.8 & 69.8 & 6 I.9 & 58.7 & $49 \cdot 5$ \\
\hline $5^{0-6 o}$ & 80.4 & 7I.9 & 63.8 & 68.7 & $55 \cdot 2$ \\
\hline \multicolumn{6}{|l|}{ Training Time Index: } \\
\hline $20-34$ & I. 55 & 2.04 & $2.4 \mathrm{I}$ & $2.2 \mathrm{I}$ & 2.44 \\
\hline $35-49$ & I. 32 & I. 82 & 2.26 & 2.34 & 2.82 \\
\hline $5^{0-6 o}$ & I.I8 & I.6I & 2.08 & I. 87 & 2.66 \\
\hline \multirow{2}{*}{\multicolumn{6}{|c|}{$\begin{array}{l}\text { Learning time (employees only): } \\
>>2 \text { years: }\end{array}$}} \\
\hline & & & & & \\
\hline $20-34$ & IO.3 & II.9 & I 4.9 & I $5 \cdot 4$ & I3. 8 \\
\hline $35-49$ & I2.5 & I6.8 & 20.0 & I9.5 & I9.I \\
\hline $5^{0-6 o}$ & $\mathrm{I} 3.2$ & $\mathrm{I} 3 \cdot 7$ & I4. I & I9.5 & 25.8 \\
\hline \multicolumn{6}{|l|}{ < I month: } \\
\hline $20-34$ & 34.6 & $25 \cdot 6$ & $29 \cdot 7$ & 24.0 & 27.2 \\
\hline $35-49$ & 37.8 & $3 \mathrm{I} \cdot 4$ & $24 \cdot 4$ & $24 \cdot 9$ & I9.5 \\
\hline $5^{0-6 o}$ & $49 \cdot 7$ & 30.1 & $33 \cdot 3$ & 26.I & 22.2 \\
\hline \multicolumn{6}{|l|}{ Learning Time Index: } \\
\hline $20-34$ & 2.68 & 2.90 & 2.95 & 3.03 & $3 . \mathrm{OI}$ \\
\hline $35^{-49}$ & 2.67 & 2.96 & 3.26 & 3.25 & $3 \cdot 47$ \\
\hline $5^{0-60}$ & 2.37 & 2.83 & 2.89 & $3 \cdot 3^{2}$ & $3 \cdot 5^{\mathrm{I}}$ \\
\hline
\end{tabular}

Note: See Table I.

knowledge demanded by the work. Respondents were asked: 'Since completing full-time education, have you ever had, or are you currently undertaking, training for the type of work that you currently do? If "yes", how long, in total, did (or will) that training last?' If training was continuing, the respondents were asked to estimate for how long. The presented analysis examined the proportions reporting 'short' (less than three 
months) and 'long' (over two years) durations, i.e. the points at either end of the continuum. We also use a summary measure of the complete range of options allowed termed the 'Training Time Index', which ranges from 'o' to ' 6 '.

The overall trends for this indicator suggest that the skills demanded at work have risen. Comparing the I986 and 2006 results shows that training times on average lengthened-greater proportions of the employed workforce reported that their job training lasted over two years, while smaller proportions reported durations of less than three months. On this evidence, older men and women again closed the skills gap with younger workers by 2006, a change from the position in 1986 when they occupied relatively low-skilled positions. For older men, the 'Training Time Index' was I.94 in I986 compared to a statistically higher $(p<0.01)$ figure of 2.65 for young men, but by 2006 the figures were insignificantly different (2.3 I and 2.40, respectively). For women, it was a similar story with older women statistically more likely to occupy less training-intensive jobs in I986 than young workers (I.I8 and I.55, $p<$ o.or), but by 2006 there was no significant difference (2.66 and 2.44).

The third broad skills measure was constructed similarly. The respondents were asked: 'How long did it take for you after you first started doing this type of job to learn to do it well?' If they answered 'still learning', they were asked: 'How long do you think it will take?' For the purposes of the presented analysis, we again examine the proportions at the extremes of the continuum - 'short' learning time denoting 'less than one month' and 'long' denoting 'over two years'. The 'Learning Time Index' is the summary measure and ranged from ' $I$ ' to ' 6 '. On this measure, the skills position of older male and female workers was reversed much earlier - sometime during the early ig9os for men, and during the late ig9os for women. Moreover, the magnitude of the change on this indicator was the most marked of the three measures. In 2006, both older men and women were in jobs that demanded significantly more $(p<$ o.or $)$ learning time than workers aged 20-34 years, a complete reversal of the situation in 1986, both in absolute terms for men and women and statistically for women.

The overall message of these results is that while older workers of both sexes used to occupy relatively low-skilled positions in the labour market, this is no longer the case. According to all three broad skill measures, in I986 men and women aged $5^{-}-59$ years were in jobs that, on average, required lower qualifications for entry, were associated with shorter training times and were quicker to learn. By 2006, parity or better had been achieved with the youngest workers in the labour market; in fact, older men and women workers were in more skilled positions than younger 
workers according to one and two of the measures, respectively, but were still in lower-skilled jobs than middle-aged workers.

Considerable attention has been given to the proposition that several identifiable 'generic' skills have risen in importance in the modern workplace. Respondents were asked a series of questions about particular activities their job might involve. So, they were asked: 'in your job, how important is [a particular job activity]?' Examples included 'caring for others', 'dealing with people', 'using a computer', 'analysing complex problems' and 'planning the activities of others'. The questionnaire covered 35 activities that spanned the tasks carried out in a wide range of jobs. The response categories were 'essential' (scored '4'), 'very important', 'fairly important', 'not very important' and 'not at all important' (scored 'o'). These questions were identical in the 1997, 200I and 2006 surveys. By subtracting the average scores for 1997 from those for 2006 for each set of activities and for each age group, we can track how skills demand had changed over the decade (see Table 3).

The results suggests that the advances made by older male workers slowed over the last decade, while for older women they continued apace. None of the ten generic skills indicators rose significantly for older male workers from 1997 to 2006, whereas eight and five of them rose significantly for middle-aged and young workers, respectively. However, older male workers' computing skills - both in terms of the importance of computer use at work and the sophistication of usage - have risen as fast as younger workers. For women, the picture is a little different in that those aged 50-6o years saw all ten generic skills along with the computing skills they use at work rise significantly over the decade. On the other hand, young women workers experienced a patchier rise in the generic skills content of their jobs, in contrast to the continued advancement of the skills content of older women's jobs throughout the last two decades. One possible explanation of these findings is that older workers who leave the labour market early are predominantly exiting low-skilled jobs and at a quicker rate than in the past. Evidence elsewhere suggests, however, that older workers who exit early do so for various motives - some taking up good early-retirement packages, and others registering themselves as unable to work because of illness - while the the flow into economic inactivity comes in roughly equal measure from older workers exiting lowskilled and high-skilled jobs (Faggio and Nickell 2003; Whiting 2005). Furthermore, this did not change substantially during 1986-2006 and so the closure of the skills gap identified here represents real gains made by older workers.

While the quantity of jobs is relatively easy to count and hence employment rates can be readily calculated, the concept of 'job quality' is 
T А в L E 3. Change in generic skills by age, Great Britain, 1997-2006

\begin{tabular}{|c|c|c|c|}
\hline \multirow[b]{2}{*}{ Generic skills $^{1}$} & \multicolumn{3}{|c|}{ Change in generic skills, I997-2006 } \\
\hline & 20-34 years & $35-49$ years & $5^{0}-60$ years \\
\hline \multicolumn{4}{|l|}{ Men: } \\
\hline Verbal & $+0.218 * * *$ & $+0.15^{8 * * *}$ & +0.062 \\
\hline Physical & -0.035 & +0.018 & $-0.177^{*}$ \\
\hline Numerical & $+0.139 *$ & $+0.132^{*}$ & +0.003 \\
\hline Manual high & +0.054 & +0.066 & $-0.152^{*}$ \\
\hline Professional communication & $+0.25 \mathrm{I}^{* * *}$ & $+0.240^{* * *}$ & +0.077 \\
\hline Planning & $+0.114^{*}$ & $+0.15^{1 * * *}$ & -0.222 \\
\hline Client communication & +0.076 & +o.IIO** & +0.003 \\
\hline Horizontal communication & $+0.187^{* * * *}$ & $+0.142^{* *}$ & +0.084 \\
\hline Problem-solving & +0.040 & $+0.098^{* *}$ & -0.032 \\
\hline Checking & $+0.15^{2 * * *}$ & $+0.13^{6 * * *}$ & +0.015 \\
\hline $\begin{array}{l}\text { Using a computer, PC, or other } \\
\text { types of computerised equipment }\end{array}$ & $+0.635^{* * *}$ & $+0.5^{8} 3^{* * *}$ & $+0.773^{* * *}$ \\
\hline Level of computer usage ${ }^{2}$ & $+0.37 \mathrm{I}^{* * *}$ & $+0.33^{I^{* * *}}$ & $+0.33^{8 * * *}$ \\
\hline \multicolumn{4}{|l|}{ Women: } \\
\hline Verbal & +o.II6 & $+0.394^{* * *}$ & $+0.306^{* * *}$ \\
\hline Physical & $+0.134^{*}$ & $+0.07 \mathrm{I}$ & $+0.288 * * *$ \\
\hline Numerical & $+0.03^{0}$ & +o.18 $\mathrm{I}^{* *}$ & $+0.232^{* *}$ \\
\hline Manual high & +0.084 & $+0.224^{* * *}$ & $+0.3^{11} 1^{* * *}$ \\
\hline Professional communication & $+0.217^{* * *}$ & $+0.387^{* * *}$ & $+0.298 * * *$ \\
\hline Planning & $+0.269 * * *$ & $+0.33^{6^{* * *}}$ & $+0.300^{* * *}$ \\
\hline Client communication & $+0.127^{* *}$ & $+0.200^{* * * *}$ & $+0.175^{* *}$ \\
\hline Horizontal communication & $+0.18 \mathrm{I} * * *$ & $+0.288 * * *$ & $+0.286^{* * *}$ \\
\hline Problem-solving & -0.067 & $+0.162^{* * *}$ & $+0.205^{* *}$ \\
\hline Checking & +0.047 & $+0.205^{* * *}$ & $+0.282^{* * *}$ \\
\hline $\begin{array}{l}\text { Using a computer, PC, or other } \\
\text { types of computerised equipment }\end{array}$ & $+0.509^{* * *}$ & $+0.648^{* * *}$ & $+0.692^{* * *}$ \\
\hline Level of computer usage ${ }^{2}$ & $+0.284^{* * *}$ & $+0.40 I^{* * * *}$ & $+0.342^{* * *}$ \\
\hline
\end{tabular}

Notes: I. All 35 activities were grouped into the ten generic skills shown. First, factor analysis was used to select those activities with the highest loadings. Then, an additive index was calculated by awarding scores according to how important each activity was in respondents' jobs (the computer use question was analysed separately). 2. Each respondent was asked to indicate, if ' using a computer, PC, or other types of computerised equipment' was part of their job, whether their level of computer use was 'straightforward', 'moderate', 'complex' or 'advanced'. Each was accompanied by a set of concrete examples. To measure the level of computer usage, non-users were given a score of o, while users were given scores of I, 2, 3 or 4 according to their level of computer use. The figures reported here refer to the change in the level of computer usage given for each age group from 1997 to 2006.

Significance levels: $* p<0 . \mathrm{I}, * * p<0.05, * * * p<0.0 \mathrm{I}$.

contested and more difficult to measure. This is because individuals value different aspects of work differently. The value placed on work attributes may depend on personal circumstances (such as age, gender and family composition) and on different outlooks on life. In addition, 'quality' indicators tend to be more attitudinal and perceptual. Large quantitative surveys commissioned by the government tend not to focus on these issues, and instead concentrate on more objective indicators. Evidence of "job quality' therefore tends to come from less-frequently conducted surveys of 
T A в L E 4. High effort, low discretion jobs by age and gender, Great Britain, I992-2006

\begin{tabular}{|c|c|c|c|c|}
\hline Age group (years) & I992 & I997 & $200 \mathrm{I}$ & 2006 \\
\hline \multicolumn{5}{|c|}{ Percentages } \\
\hline \multicolumn{5}{|l|}{ Men: } \\
\hline $20-34$ & 27.0 & $3^{8.8}$ & $43 \cdot 6$ & $4^{1} .2$ \\
\hline $35^{-49}$ & 22.2 & 29.8 & 30.7 & 30.0 \\
\hline $5^{0}-6 o$ & $\mathrm{I} 9 \cdot 7$ & 22.3 & 28.7 & 28.2 \\
\hline \multicolumn{5}{|l|}{ Women: } \\
\hline $20-34$ & $25 \cdot 7$ & $35 \cdot 7$ & 40.0 & 44.2 \\
\hline $35-49$ & $2 \mathrm{I} \cdot 3$ & $3^{I} \cdot 5$ & $34 \cdot 5$ & 32.6 \\
\hline $5^{0-6 o}$ & $2 \mathrm{I} \cdot 7$ & 34.8 & $35 \cdot 2$ & 35.8 \\
\hline
\end{tabular}

Note: This table is based on responses to five questions. Four relate to the level of control employees have over: how hard they work; the tasks they carry out; the way tasks are completed; and the standards to which they work. Those who have no or little control over at least one of these aspects of work are classified as occupying 'low discretion jobs'. A fifth question asks respondents whether they agree or disagree on a four-point Likert scale to the statement that 'my job requires that I work very hard'. Those who agree or strongly agree to this statement and are in 'low discretion jobs' are classified as occupying 'high effort, low discretion jobs'.

the character drawn on here. These surveys have shown that increasing proportions of workers agree that they are required to 'work very hard'. There was substantial work intensification between 1992 and 200I, but subsequently little change (Green 2006). Since stress and anxiety are thought to be the product of excess work effort and increasing work pressure, we combine the responses to a number of survey questions in order to identify jobs that are 'high strain' (Karasek 1979). These are jobs for which workers report high work effort along with low job control, and can be identified as those for which respondents 'strongly agree' or 'agree' with the statement that 'my job requires that I work very hard' and have little say over at least one of the following: work intensity, task selection, task execution, and quality standards. An analysis by age suggests that among older workers, exposure to 'high strain' jobs increased from around one-fifth of the male and female cohorts in 1992 to over one-quarter $(28.2 \%)$ of men and one-third (35.8\%) of women in 2006 (see Table 4), similar to the growth rate for the younger cohorts. Moreover, in relative terms little appears to have changed; in both 2006 and 1992 older workers were relatively advantaged in terms of their lesser exposure to jobs most likely to reduce wellbeing and raise levels of depression (Green 2008). So, although workers of all ages experienced an intensification of work and a decline in autonomy over the last 15 years, age differences remained with older workers under relatively less strain than younger workers. 
T A B L E 5. Organisational commitment by age and gender, Great Britain, 1992-2006

\begin{tabular}{|c|c|c|c|c|}
\hline Age group (years) & I992 & 1997 & $200 \mathrm{I}$ & 2006 \\
\hline \multicolumn{5}{|c|}{ Index of Organisational Commitment } \\
\hline \multicolumn{5}{|l|}{ Men: } \\
\hline $20-34$ & 0.176 & $0.17 \mathrm{I}$ & $0.22 \mathrm{I}$ & 0.207 \\
\hline $35-49$ & 0.270 & $0.3^{82}$ & $0.35^{\mathrm{I}}$ & 0.297 \\
\hline $5^{0-60}$ & 0.453 & $0.45^{8}$ & 0.253 & 0.229 \\
\hline \multicolumn{5}{|l|}{ Women: } \\
\hline $20-34$ & 0.235 & 0.248 & 0.287 & 0.182 \\
\hline $35-49$ & 0.288 & 0.346 & 0.329 & 0.284 \\
\hline $50-60$ & 0.539 & 0.539 & $0.3^{82}$ & 0.270 \\
\hline
\end{tabular}

Note: Respondents were asked: 'Thinking about your feelings towards the organisation you work for, I would like to ask you to what extent you agree or disagree with the following statements. First: 'I am willing to work harder than I have to in order to help this organisation succeed'. Respondents were asked to use a four-point agreement scale. Second: 'I feel very little loyalty to this organisation' (note reversal). Third: 'I find that my values and the organisation's values are very similar'. Fourth: 'I am proud to be working for this organisation'. Fifth: 'I would take almost any job to keep working for this organisation'. Lastly: 'I would turn down another job with more pay in order to stay with this organisation'. The figures shown are the summary 'Index of Organisational Commitment' derived from responses to the individual questions.

Increasing work pressure appears to have had a greater effect on the organisational commitment of older workers than of younger employees. It is often heard that older workers are more committed to the organisations they work for-this commonplace assumption can be found in popular discourse and has been supported by researchers (e.g. Taylor and Walker I994). The evidence presented here suggests although this may have been correct in the past, it is no longer the case. While White's (2009) recently published analysis of $1992-2000$ data was the first to question the assumption, the analysis in this paper extends to 2006, makes use of four rather than two data points, and uses the conventional definition of older workers as those aged 50 or more years. Organisational commitment is defined as 'feelings of attachment to goals and values of the organisation, one's role in relation to this, and attachment to the organisation for its own sake rather than for its strictly instrumental value' (Cook and Wall ig80: 40). From this, survey questions have been developed which tap employees' attitudes towards their organisations and their behaviour at work. The four surveys reported here asked respondents six questions that are widely used to derive levels of organisational commitment - three relate to employee attitudes and three to employee behaviour. Respondents were asked to indicate, on a four-point Likert scale, their level of agreement or disagreement with six statements, including: 'I find that my and the organisation's values are very similar' and 'I would turn down another job with more pay in order to stay with this organisation' (see Table 5 for more 
detail). For the analysis, we first awarded values of ' 2 ' for 'strongly agree', ' I' for 'agree', ' - I' for 'disagree' and ' -2 ' for 'strongly disagree', and then created an 'Index of Organisational Commitment' by adding the scores and dividing by six. Statistical tests confirmed that the resulting measure captured a good proportion of the inter-correlation in the sixitem index (Cronbach's alpha is 0.79).

The evidence suggests that the organisational commitment of older workers remained relatively high throughout the ig9os, but fell sharply in the new millennium. Until recently, then, there was some substance in the claim that older workers had a greater attachment than younger workers to the organisations for which they worked, but age differences have become negligible for men and only slight for women. A possible explanation is that - irrespective of their employment experiences - workers who entered the labour market during the ig6os were less deferential and more independently minded than previous generations, but the data provide little support for this hypothesis. Those who entered the labour market in the Ig6os, and hence were aged 50-6o years in the 2006 survey, had lower - often significantly lower - organisational commitment scores than those aged $45^{-5} 5$ years in 200I, 4I-5 ${ }^{\mathrm{I}}$ years in 1997 and $3^{6-46}$ years in I992 (using pseudo cohort analysis). This suggests that falling levels of organisational commitment among older workers cannot be explained by generational replacement alone. A fuller explanation of falling levels of organisational commitment awaits further analysis, but it is noticeable that older workers in the public sector had a level of commitment that more than halved during I992-2006, while for younger workers it did not change significantly at all. The pattern was stronger for men.

Another possible explanation is that older workers perceive the increased skills content of their jobs negatively rather than positively, and are more resentful of the increased work pressures that employees of all ages have faced. It may be older workers that particularly regard both changes as unwelcome burdens at their time of life, which might explain the steep fall in their loyalty towards the organisations they hold responsible. To test this further, we examined how employees' commitment to work in general changed over the period. To gauge their employment commitment, we asked: 'if you were to get enough money to live as comfortably as you would like for the rest of your life, would you continue to work, not necessarily in your present job, or would you stop working?' Those who said they would continue working were then asked: 'Ideally, how many hours a week would you like to work if you didn't need the money?' Despite the steep fall in the organisational commitment of older workers reported in this paper and by White (2009), employment commitment remained remarkably stable. Over one-half of those aged in the 
T A в L E 6. Employment commitment by age and gender, Great Britain, 1992-2006

\begin{tabular}{|c|c|c|}
\hline Gender, commitment and age group (years) & 1992 & 2006 \\
\hline \multicolumn{3}{|l|}{ Men: } \\
\hline \multicolumn{3}{|l|}{ Commitment to continue working: } \\
\hline $20-34$ & $74 \cdot 4$ & $75 \cdot 3$ \\
\hline $35-49$ & 64.7 & 63.4 \\
\hline $50-60$ & 57.6 & 56.4 \\
\hline \multicolumn{3}{|l|}{ Commitment to continue working full-time ${ }^{1}$ : } \\
\hline $20-34$ & 39.0 & 22.7 \\
\hline $35-49$ & 36.3 & $2 \mathrm{I} .3$ \\
\hline $50-60$ & $28 . \mathrm{I}$ & I5.O \\
\hline \multicolumn{3}{|l|}{ Commitment to continue working part-time: } \\
\hline $20-34$ & 35.5 & 52.6 \\
\hline $35-49$ & 28.4 & $42 . \mathrm{I}$ \\
\hline $5^{0-60}$ & 29.5 & $4^{\mathrm{I} \cdot 4}$ \\
\hline \multicolumn{3}{|l|}{ Women: } \\
\hline \multicolumn{3}{|l|}{ Commitment to continue working: } \\
\hline $20-34$ & 76.0 & 73.8 \\
\hline $35^{-49}$ & $64 \cdot 9$ & 65.0 \\
\hline $50-60$ & 50.4 & $54 \cdot 5$ \\
\hline \multicolumn{3}{|l|}{ Commitment to continue working full-time: } \\
\hline $20-34$ & 17.2 & 9.2 \\
\hline $35-49$ & II.7 & 5.8 \\
\hline $5^{0-6 o}$ & IO.I & 5.9 \\
\hline \multicolumn{3}{|l|}{ Commitment to continue working part-time: } \\
\hline $20-34$ & 58.8 & 64.7 \\
\hline $35-49$ & 53.2 & 59.2 \\
\hline $5^{0-60}$ & 40.3 & 48.6 \\
\hline
\end{tabular}

Note: I. Full-time work was defined as 30 hours or more a week; part-time as less than 30 hours.

fifties would remain in work even if they had no financial need to do so (see Table 6). Employment commitment did decline with age, but the pattern changed little during 1992-2006, with those aged 20-34 years the most likely to stay in work regardless of their financial circumstances (three-quarters reported wanting to remain in work). These patterns applied to both men and women (although older men working in the public sector had declining employment commitment over time).

The commitment to full-time employment fell rapidly. Whereas in 1992 employment commitment among men was split more or less evenly between full-time and part-time work in all age groups, by 2006 part-time work was favoured by around two-in-three who said that they would continue working even if they did not have to do so for financial reasons. This shift occurred more or less evenly across all three age groups. The attraction of part-time working for women - already relatively high in I992 - also increased over time, albeit less sharply than for men. In I992, four-in-five women aged in the fifties who said that they would carry on working even if they had enough money to live on would have done so by 
working part-time, but by 2006 the proportion had risen to nine-in-ten. The attractions of working full-time for both men and women of all age groups fell during I992-2006, although the attractions of work itself changed little. Taken together, these results suggest that older workers of both sexes have become far less committed to their current employers since the early I99os and would prefer - like young and middle-aged workers - to reduce their hours of work. These patterns were most pronounced for male public-sector workers.

Many analysts have shown that older workers are less likely to receive training than their younger counterparts (e.g. McNair 2009; Taylor and Urwin 200I; Urwin 2004). This is seen as another labour-market disadvantage and has led to legislation which promotes equal access to training for workers of all ages. It is unclear, however, whether declining participation in training by age is the result of employer unwillingness to train older workers or the reluctance of older workers to take it up. Moreover, the quality of training may differ by age. Previous research has suggested, for example, that not all training episodes are intended to raise skills by the same amount and some are not about raising skill levels at all. Instead, some training is designed to enhance employee commitment and has little to do with raising skills, and some aims to ensure conformity with standardised and prescribed ways of working which restrict the skills used at work (Felstead et al. 2007a, 2009). The quality of training can differ in other respects too. For example, even where skills are acquired as a result of training, they may or may not be important enough for the employer to award a pay rise. The quality of training may also differ according to whether or not it raises levels of job satisfaction and enjoyment. Focusing exclusively on the incidence and intensity of training - for which older workers are at a disadvantage - fails to acknowledge the many ways in which the quality of training episodes differ and create another source of labour-market disadvantage. An important aspect of the 2006 Skills Survey was the addition of a set of questions designed to shed light on these issues and asked of employees aged 20-65 years.

The results confirm that the incidence of training declines sharply with age for both men and women (see Table 7). In general, those who received training rated its impact on their performance as high, but the ratings fell a little with greater age. For example, men and women in their fifties who received training were a little less likely than their younger counterparts to say that it had improved their skills and working practices. More notably, the training they received was far less likely to result in a pay rise or to add to their enjoyment of work. So, older workers have been less likely to participate in training, and even when they did it was likely to be of slightly poorer quality. It is commonly assumed that employers are reluctant to 


\section{T A B L E 7. Training and its quality by age and gender, United Kingdom, 2006}

\begin{tabular}{|c|c|c|c|c|c|}
\hline \multirow[b]{2}{*}{$\begin{array}{l}\text { Gender and age } \\
\text { group (years) }\end{array}$} & \multirow[b]{2}{*}{$\begin{array}{l}\text { Training } \\
\text { incidence }^{1}\end{array}$} & \multicolumn{4}{|c|}{ Quality } \\
\hline & & $\begin{array}{l}\text { Has raised skills } \\
\text { used at work } \\
\text { a little or a } \operatorname{lot}^{2}\end{array}$ & $\begin{array}{l}\text { Has improved } \\
\text { working } \\
\text { practices }^{3}\end{array}$ & $\begin{array}{l}\text { Pay increased } \\
\text { following } \\
\text { training }{ }^{4}\end{array}$ & $\begin{array}{l}\text { Enjoy } \\
\text { job } \\
\text { more }^{5}\end{array}$ \\
\hline & & & Percentages & & \\
\hline \multicolumn{6}{|l|}{ Men: } \\
\hline $20-34$ & 68.8 & 93.2 & 89.4 & 30.0 & 60.4 \\
\hline $35-49$ & $71 \cdot 4$ & 9I.I & 86.2 & I3.3 & 57.I \\
\hline $5^{0-65}$ & $55 . \mathrm{I}$ & 85.7 & 80.0 & 9.0 & 52.0 \\
\hline \multicolumn{6}{|l|}{ Women: } \\
\hline $20-34$ & 72.3 & 92.4 & 88.4 & 24.9 & 64.7 \\
\hline $35-49$ & $69 . \mathrm{I}$ & 92.0 & 85.9 & $\mathrm{I} 5.3$ & 63.0 \\
\hline $5^{0-65}$ & 60.8 & 90.I & 85.2 & 8.4 & 57.7 \\
\hline
\end{tabular}

Notes: I. Respondents were asked: 'In the last year (that is since [Month] 2005), have you done any of these types of training or education connected with your current job?' The card of options included the following: 'received instruction or training from someone which took you away from your normal job' (off-the-job); 'received instruction whilst performing your normal job' (on-the-job); 'taught yourself from a book/manual/video/computer/cassette' (self taught); 'followed a correspondence or Internet course (such as Open University (at a distance))'; 'taken an evening class' (out-of-hours class); 'done some other work-related training' (other work-related); and 'none of these'. The table presents the proportion of employees in the sample reporting at least one of these activities. 2. The percentage of trainees who responded 'a lot' or 'a little' to the question: 'Would you say that this training or education has improved your skills ...' (the other alternative response was 'not at all') and confirmed that they 'are able to make use of these skill improvements in your current job'. 3 . The percentage of trainees who agreed with the statement: 'The training has helped me improve the way I work in my job'. 4 . Those in receipt of training were asked whether they agreed with the statement: 'I received a pay increase as a result of my training'. 5. Respondents were asked: 'Still thinking about the training you received over the last year in your current job, which of the following statements apply?'. Among the list was the following statement: 'The training has made me enjoy my job more'.

train older workers because the pay-back period is relatively short, or because older workers are more resistant to new ideas and have little new to learn at their time of life. On this basis, we would expect the reasons for and consequences of not receiving training to vary with age, but employers' reluctance to offer training in the face of an employee's demand was reported by, if anything, a slightly higher proportion of younger workers. This suggests that employers' reluctance to offer training hinders the training prospects of the young more than the old (see Table 8). As expected, however, attitudes towards training varied with age. For example, around two-thirds of older men and women said that they 'did not want any training' compared to between one-third and two-fifths of younger workers.

Similarly, the perceived drawbacks of not receiving training - in terms of the requirements of the job and the enhancement of the prospect of promotion - also fell with age. Smaller proportions of older workers also 
T A B L E 8. Reasons for and consequences of the lack of training by age and gender, United Kingdom, 2006

\begin{tabular}{|c|c|c|c|c|c|c|}
\hline \multirow[b]{2}{*}{$\begin{array}{l}\text { Gender and age } \\
\text { group (years) }\end{array}$} & \multicolumn{4}{|c|}{ Reasons given } & \multicolumn{2}{|c|}{ Consequences } \\
\hline & $\begin{array}{c}\text { Wanted } \\
\text { but not } \\
\text { given }^{1}\end{array}$ & $\begin{array}{l}\text { Did not } \\
\text { want }^{2}\end{array}$ & $\begin{array}{l}\text { Did not } \\
\text { need }^{3}\end{array}$ & $\begin{array}{l}\text { No pay } \\
\text { off }^{4}\end{array}$ & $\begin{array}{l}\text { Failing to } \\
\text { keep up } \\
\text { to date }\end{array}$ & $\begin{array}{l}\text { Damaging } \\
\text { to career }\end{array}$ \\
\hline & \multicolumn{6}{|c|}{ Percentages } \\
\hline \multicolumn{7}{|l|}{ Men: } \\
\hline $20-34$ & 24.9 & $37 \cdot 1$ & $69 \cdot 4$ & 5 I.6 & 23.0 & I0.9 \\
\hline $35^{-49}$ & 17.7 & $5^{0.9}$ & $69 \cdot 5$ & $55 \cdot 6$ & $26 . \mathrm{I}$ & 12.8 \\
\hline $5^{0-65}$ & I7.4 & 62.4 & $74 \cdot 7$ & $65 \cdot 5$ & 22.6 & 6.2 \\
\hline \multicolumn{7}{|l|}{ Women: } \\
\hline $20-34$ & I6.4 & 4I.9 & $5^{8.5}$ & $4 \mathrm{I} \cdot 5$ & $24 \cdot 5$ & $6 . \mathrm{I}$ \\
\hline $35-49$ & I 4.8 & $5^{6.0}$ & 70.3 & $55 \cdot 7$ & $20 . \mathrm{I}$ & 8.0 \\
\hline $5^{0-65}$ & $9 \cdot 4$ & 65.6 & 72.8 & 6 I.8 & I6.6 & $4 \cdot 4$ \\
\hline
\end{tabular}

Notes: I. Respondents were asked: 'You have said that you have not received any training over the last year in your current job. Which of the following statements apply?' Respondents were asked whether they agreed or disagreed with the statements presented. For this column, we report the percentage who agreed with the statement: 'My employer was not willing to provide additional training, even though I wanted it'. 2. The percentage who agreed with the statement: 'I did not want any training'. 3. The percentage who agreed with the statement: 'I did not need any additional training for my current job'. 4. The percentage who agreed with the statement: 'Training would not help me get a better job in my organisation'. 5 . Respondents who undertook no training during the year before interview were asked: 'Was there any time over the last year in your current job when training would have been useful for keeping up to date with the skills required?' The table presents the results of those who said 'yes'. 6. These respondents were also asked whether they agreed or disagreed with the statement that: 'Lack of training damaged my career opportunities'.

thought that the lack of training made it difficult for them to keep pace with changes in the job and few thought it hindered their career opportunities. The reported need for training also declined with age approaching three-quarters $(72.8 \%)$ of older-women workers reported that they did not receive training because it was not needed for their current job, compared to three-fifths $(58.5 \%)$ of those aged $20-34$ years. From this, we can conclude that employers do not appear overly to resist providing training for older workers. Older workers not in receipt of training rated the benefits of training lower than their younger counterparts, however, and even when those who received training considered it less beneficial than younger employees ( $c f$. Table 8).

\section{Conclusions}

Britain's population is ageing, and even before the financial crisis brought about by the collapse of the banking system, the country was on course for 
a Malthusian crisis of supporting a growing number of older people from a declining relative number of younger tax-payers. For more than a decade, the public policy response has been to encourage more people to delay their retirement. While this has been successful in that the employment rate of older workers has increased since the early iggos, some concerns have been raised that this has been at the cost of a decline in the quality of working lives. The aim of this paper has been to assess whether such concerns are justified. To do so, the paper has presented new empirical evidence on how the quality of older-workers' employment currently compares to that of younger cohorts and how this has changed over the last two decades. It has examined the skills content of jobs, the intensity and discretion levels of work, the loyalty of workers towards their current employer and their attachment to employment in general, and the quality of the training experience and the scale of the disappointment among those not in receipt of training.

In recent times, the position of older workers in the labour market has improved in two ways. First, older workers have closed the gap with young workers in areas where they were previously disadvantaged. For example, the skills content of jobs differed significantly by age group in I986, with older workers holding lower-skilled jobs much more than younger workers. By 2006, however, this disadvantage had disappeared for both sexes, although middle-aged workers still occupied the most skilled positions. Secondly, older workers have maintained some of the relative advantages they have long enjoyed. For example, while over the last two decades all workers have experienced an intensification of work and a decline in autonomy, age differences have been maintained with older workers under relatively less pressure than their young or middle-aged contemporaries. Nonetheless, despite closing the skills gap and maintaining some of the labour-market advantages of age, the loyalty of older workers to their immediate employer-but not employment in general-fell sharply after I992. Older workers, though, have been disadvantaged in terms of receiving training, and moreover when provided it tended to be of a lower quality than that received by younger employees. The motivation to learn does appear to be lower among older workers, however, and their training deficit is widely regarded as of less consequence than for those aged less than $5^{0}$ years.

Overall, then, it does appear that some of the age gaps in the labour market have been closing - as found by other researchers but using a narrower range of indicators (e.g. Taylor 2008). However, the sustainability of these gains will be put to the test in the current recession and as policy makers again focus on tackling the needs of the young. This is especially the case in current circumstances since, unlike in previous 
recessions when older workers were encouraged and able to take early retirement, its attractions have diminished as pension funds have shrunk and government has encouraged the extension of working life as one solution to the financial consequences of an ageing population. The results presented here provide a benchmark against which to test the sustainability of these gains against the results of future surveys. In the meantime, there is some comfort in the weakening importance of age as a differentiator in segmented labour markets, even though closing some of the age gaps may only be short-lived.

\section{Acknowledgements}

The 2006 Skills Survey on which this paper is partly based was supported by grants from the UK Economic and Social Research Council, the Department for Education and Skills, the Department of Trade and Industry, the Learning and Skills Council, the Sector Skills Development Agency, Scottish Enterprise, Futureskills Wales, Highlands and Islands Enterprise, East Midlands Development Agency, and the Department for Employment and Learning, Northern Ireland. I would also like to thank Lucy Sims for helping me with the literature search, my colleagues - Francis Green and Duncan Gallie - with whom I worked to devise and carry out several of the surveys reported here, Nick Jewson, the Editor, Associate Editor and the three referees for offering comments and suggestions on earlier versions of the paper. However, the usual caveat applies.

\section{References}

Ashton, D., Davies, B., Felstead, A. and Green, F. 1999. Work Skills in Britain. ESRC Centre on Skills, Knowledge and Organisational Performance, Oxford.

Barnes, H., Smeaton, D. and Taylor, R. 2009. An Ageing Workforce: The Employer's Perspective. Report 468, Institute for Employment Studies, Brighton, UK.

Brooke, L. 2009. Prolonging the careers of older information technology workers: continuity, exit or retirement decisions? Ageing \& Society, 29, 2, 237-56.

Cook, J. and Wall, T. I980. New work attitude measures of trust, organizational commitment and personal need and non-fulfilment. Fournal of Occupational Psychology, 53, I, $39^{-52 .}$

Department for Work and Pensions 2005. Opportunity Age. Stationery Office, London.

Disney, R. and Hawkes, D. 2003. Why has employment recently risen among older workers in Britain? In Dickens, R., Gregg, P. and Wadsworth, J. (eds), The Labour Market Under New Labour: The State of Working Britain. Palgrave, London, 53-69.

Dunnell, K. 2008. Ageing and mortality in the UK: National Statistician's annual article on the population. Population Trends, I34, 6-23.

European Commission. 2003. Employment in Europe: Recent Trends and Prospects. Office for Official Publications of the European Communities, Luxembourg.

Faggio, G. and Nickell, S. 2003. The rise in inactivity among adult men. In Dickens, R., Gregg, P. and Wadsworth, J. (eds), The Labour Market Under New Labour: The State of Working Britain. Palgrave, London, $4^{0}-52$. 
Felstead, A., Gallie, D. and Green, F. 2002. Work Skills in Britain, I986-200I. Department for Education and Skills, London.

Felstead, A., Fuller, A., Jewson, N., Kakavelakis, K. and Unwin, L. $2007 a$. Grooving to the same tunes? Learning, training and productive systems in the aerobics studio. Work, Employment and Society, 2 I, 2, I89-208.

Felstead, A., Gallie, D., Green, F. and Zhou, Y. 2007b. Skills at Work, 1986-2006. ESRC Research Centre on Skills, Knowledge and Organisational Performance, Oxford.

Felstead, A., Fuller, A., Jewson, N. and Unwin, L. 2009. Improving Working as Learning. Routledge, London.

Gallie, D., White, M., Cheng, Y. and Tomlinson, M. 1998. Restructuring the Employment Relationship. Clarendon, Oxford.

Green, F. 2006. Demanding Work: The Paradox of Work Quality in the Affluent Economy. Princeton University Press, Princeton, New Jersey.

Green, F. 2008. Work effort and worker well-being in the age of affluence. In Burke, R. and Cooper, G. (eds), The Long Work Hours Culture: Causes, Consequences and Choices. Emerald Group, Bradford, UK, II5-34.

Higgs, P., Mein, G., Ferrie, J., Hyde, M. and Nazroo, J. 2003. Pathways to early retirement: structure and agency in decision-making among British civil servants. Ageing $\mathbb{E}$ Society, 23, 6, 76I-78.

Hirsh, D. 2003. Crossroads After 50: Improving Choices in Work and Retirement. Joseph Rowntree Foundation, York, UK.

Hotopp, U. 2005. The employment rate of older workers. Labour Market Trends, ro9, 2, 73-88.

Humphrey, A., Costigan, P., Pickering, K., Stratford, N. and Barnes, M. 2004. Factors Affecting the Labour-market Participation of Older Workers. Research Report 200, Department for Work and Pensions, Her Majesty's Stationery Office, Norwich, UK.

Karasek, R. A. i979. Job demands, job decision latitude, and mental strain: implications for job redesign. Administrative Science Quarterly, 24, 2, 285-308.

Khan, K. 2009. Employment of the older generation. Economic and Labour Market Review, 3, $4,30-6$.

Laczko, F. and Phillipson, C. I99. Changing Work and Retirement: Social Policy and the Older Worker. Open University Press, Milton Keynes, UK.

Lissenburgh, S. and Smeaton, D. 2003. Employment Transitions of Older Workers: The Role of Flexible Employment in Maintaining Labour-market Participation and Promoting Fob Quality. Policy Press, Bristol, UK.

Lutz, W. 2008. European Demographic Datasheet 2008. Vienna Institute of Demography, Vienna. Available online at http://www.oeaw.ac.at/vid/datasheet/download/ European_Demographic_Data_Sheet_2008.pdf [Accessed I2 March 2009].

McNair, S. 2006. How different is the older worker labour market? Attitudes to work and retirement among older people in Britain. Social Policy and Society, 5, 4, 485-94.

McNair, S. 2009. Demography and Lifelong Learning. Paper I, NIACE Inquiry into the Future of Lifelong Learning Thematic, National Institute of Adult Continuing Education, Leicester, UK.

McNair, S. and Flynn, M. 2005. The Age Dimension of Employment Practices: Employer Case Studies. Employment Relations Research Series 42, Department of Trade and Industry, London.

Meadows, P. 2003. Retirement Ages in the UK: A Review of the Literature. Employment Relations Research Series i8, Department of Trade and Industry, London.

Metcalf, H. and Meadows, P. 2006. Survey of Employers' Policies, Practices and Preferences Relating to Age. Research Report 325, Department for Work and Pensions, Stationery Office, Norwich, UK. 


\section{I3I4 Alan Felstead}

Minister of State for Employment 2006. The Employment Equality (Age) Regulations, Statutory Instrument 2006 No. IO3I. Stationery Office, London. Available online at http://www. opsi.gov.uk/si/si20o6/uksi_2006ı03I_en.pdf [Accessed 20 May 20ı0].

Penn, R., Rose, M. and Rubery, J. (eds) r994. Skill and Occupational Change. Oxford University Press, Oxford.

Phillipson, C. and Smith, A. 2005. Extending Working Life: A Review of the Research Literature. Research Report 299, Department for Work and Pensions, Stationery Office, Norwich, UK.

Platman, K. 2004. Flexible employment in later life: public policy panaceas in the search for mechanisms to extend working lives. Social Policy and Society, 3, 2, I8I-8.

Platman, K. and Tinker, A. I998. Getting on in the BBC: a case study of older workers. Ageing \& Society, 18, 5, 513-35.

Smeaton, D., Vegeris, S. and Sahin-Dikmen, M. 2009. Older Workers: Employment Preferences, Barriers and Solutions. Research Report 43, Equality and Human Rights Commission, Manchester, UK.

Stein, D., Rocco, T. S. and Goldenetz, K. A. 200o. Age diversity and the university workplace: a case study of remaining, retiring, or returning older workers. Human Resource Development Quarterly, I I, I, 6I-80.

Taylor, P. 2008. Sing if you're glad to be grey: working towards a happier older age in the United Kingdom. In Taylor, P. (ed.), Ageing Labour Forces: Promises and Prospects. Edward Elgar, Cheltenham, UK, 84-IIo.

Taylor, P. and Urwin, P. 200 . Age and participation in vocational education and training. Work, Employment and Society, I 5, 4, 763-79.

Taylor, P. E. and Walker, A. I994. The ageing workforce: employers' attitudes towards older people. Work, Employment and Society, 8, 4, 569-9I.

Turner, A. 2006. A New Pension Settlement for the Twenty First Century: Second Report of the Pensions Commission. Department for Work and Pensions, London.

Urwin, P. 2004. Age Matters: A Review of Existing Survey Evidence. Employment Relations Research Series 24, Department of Trade and Industry, London.

Vickerstaff, S. 2006. 'I'd rather keep running to the end and then jump off the cliff': retirement decisions: who decides? Fournal of Social Policy, 35, 3, 455-72.

Villosio, C. 2008. Working Conditions of an Ageing Workforce. European Foundation for the Improvement of Living and Working Conditions, Dublin.

Walker, A. 2004. The ESRC 'Growing Older' research programme, I999-2004. Ageing \& Society, 24, 5, 657-74.

White, M. 2009. Work orientations of older employees: change over the gos and into the oos. Discussion paper (new series) 3, Policy Studies Institute, London.

Whiting, E. 2005. The labour-market participation of older workers. Labour Market Trends, го9, $7,285-96$.

Address for correspondence:

Alan Felstead, Cardiff School of Social Sciences,

Cardiff University, Glamorgan Building,

King Edward VII Avenue, Cardiff CFIo 3WT, UK

E-mail: alanfelstead@cf.ac.uk 